\title{
Harnessing the Power of Eph/ephrin Biosemiotics for Theranostic Applications
}

\author{
Robert M. Hughes ${ }^{1}$ (1) and Jitka A.I. Virag ${ }^{2, *}$ (D) \\ 1 Department of Chemistry, East Carolina University, Science and Technology Building, SZ564, East 5th St, \\ Greenville, NC 27858, USA; hughesr16@ecu.edu \\ 2 Department of Physiology, Brody School of Medicine, East Carolina University, \\ Warren Life Sciences Building, LSB239, 600 Moye Blvd, Greenville, NC 27834, USA \\ * Correspondence: viragj@ecu.edu
}

Received: 11 April 2020; Accepted: 27 May 2020; Published: 1 June 2020

\begin{abstract}
Comprehensive basic biological knowledge of the Eph/ephrin system in the physiologic setting is needed to facilitate an understanding of its role and the effects of pathological processes on its activity, thereby paving the way for development of prospective therapeutic targets. To this end, this review briefly addresses what is currently known and being investigated in order to highlight the gaps and possible avenues for further investigation to capitalize on their diverse potential.
\end{abstract}

Keywords: Eph/ephrin; receptor tyrosine kinase; therapeutic target; smart drug; nanoparticles; liposomes; exosomes

\section{Introduction}

Detection, transduction and appropriate response behavior of neighboring cells are essential components of optimal communication and the coordinated and integrated function necessary for survival. In a complex system, this is determined by the summative and timely intracellular processing of a myriad of intersecting signals from various distances and directions. The Eph receptors and ephrin ligands are the largest tyrosine kinase (RTK) superfamily, comprised of 22 known members, subdivided into A- and B-subclasses, and are heterogeneously expressed in almost every tissue [1]. These membrane-anchored proteins exhibit unique cell-to-cell communication via bidirectional signaling, which modulates cytoskeletal dynamics and thus cell-cell recognition and motility, making them integral mediators in developmental processes and the maintenance of homeostasis [2,3]. Given the importance of these biomolecules, it stands to reason that derangements in expression and signaling sequelae would contribute to and/or cause disease [4-10]. The disparate influences of aging, ethnicity, and gender on expression and signaling variations, however, which may exacerbate pre-existing imbalances, remain largely unexplored. Their complicated expression profiles, often with multiple ligands and/or receptors on one cell adjacent to or near other(s) with a different expression profile, compounded by their various affinities for receptor binding, oligomerization, cis- and trans-activation or inhibition, all contribute to the complicated delineation of their roles in normal physiology and disease progression, as well as development of customized, targeted therapeutics [11-17].

\section{Eph/ephrin is a Ubiquitous Therapeutic Target}

The Eph receptors (Eph = erythropoietin-producing hepatocellular) and their congeneric ligands, the ephrins (contraction of "Eph receptor interacting proteins" and after the Greek word "ephoros" meaning overseer or controller), are the largest family of receptor tyrosine kinases, comprised of 14 receptors and 8 ligands. Since their discovery and cloning by Hirai et al., published in Science in 1987 [18], more than 5000 articles have reported on the structure of these proteins, cellular 
and tissue expression profiles, downstream signaling mechanisms, and their contribution to the differentiation, proliferation and migration of various cell types. Ligands A1-A5 and B1-B3 are typically membrane-anchored, and cell-to-cell contact is usually but not always required, resulting in binding with varying affinity and promiscuity to the receptors A1-A8, A10, B1-B4, and B6. Subsequent dimerization, tetramerization and/or clustering of ligands and receptors (Figure $1 \mathrm{~A}$ ) can cause activation or silencing of bi-directional signaling and consequent activation (or inhibition) of intracellular cascades in each cell [19-24]. Ojosnegros et al. (2017) recently adapted enhanced fluorescence fluctuation imaging analysis to resolve the spatial relationships of polymerization and formation of larger aggregates, generating a model of polymerization-condensation dynamics which suggests that these associations result not only in amplification of the signal, but also in termination [25]. To complicate matters, domain mutation analyses have revealed that the nature of the contact interfaces in the ligand-binding domains confer binding specificity, but it is the domains contained within ectodomains (e.g., SAM-sterile alpha motif) that are indispensable for localization and subsequent forward intracellular signaling [26-28]. Lastly, the importance of the lipid bilayer composition [29], as well as its interface as a regulator of their orientation and configuration with respect to the membrane, as demonstrated by charge-swapping simulations [30], illustrates their effectual plasticity.

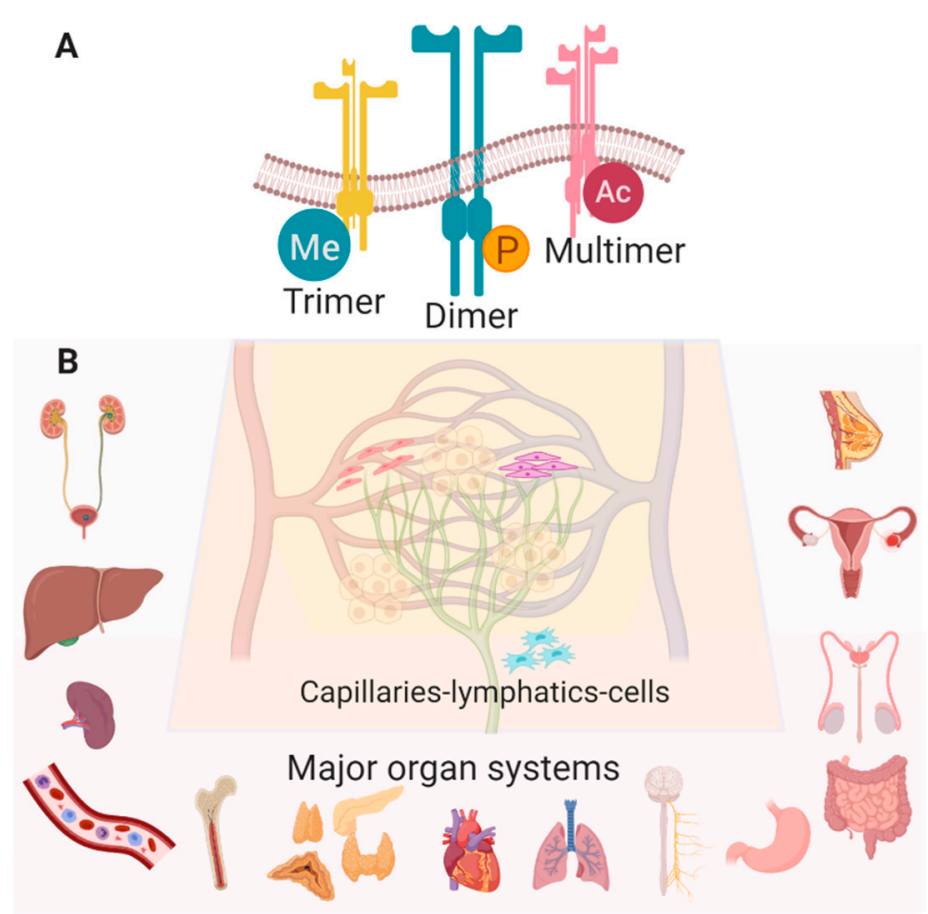

Figure 1. (A) Many configurations and post-translational modifications of Eph/ephrin RTKs have been observed (Me-methylation, P-phosphorylation, Ac—acetylation). (B) Eph/ephrin RTKs are widely expressed in various cell types in most healthy tissues with the following exceptions: EphA8 is detected only in spleen, brain and testes, EphA10 is in testes only, and ephrinA2 is absent in lung, spleen, testes, and bone marrow (Created with BioRender.com).

The multifaceted and ubiquitous expression of Eph/ephrin RTKs in nearly all cells of the body, although most extensively studied in cancer and development, implicates them in the majority of vital physiologic processes (Figure 1B) [3]. The knowledge we have acquired from these studies has generated valuable information about the role of Eph/ephrin RTKs in cellular communication and behavior, providing a wealth of therapeutic targeting opportunities that may be exploited for a range of pathologies, including but not limited to atherosclerosis [5,31,32], neurodegenerative/cognitive and endocrine disorders [33-38], gastrointestinal and genito-urinary maladies [39-41], immune disorders [4,5,9], musculoskeletal growth and metabolism diseases [42-45], 
ischemic tissue injury [46-56] and malignancies [7,57,58], reproductive/fertility illnesses [59-62] and organ fibrosis $[10,63]$. A recently observed connection between viral infections and tumorigenesis mediated through Eph/ephrins is also being characterized, raising the possibility of alternative anti-viral strategies [64]. This review aims to illustrate the potential for developing targeted vehicles, targeting methods, and therapeutic cargo to modulate Eph/ephrin signaling (Figure 2).

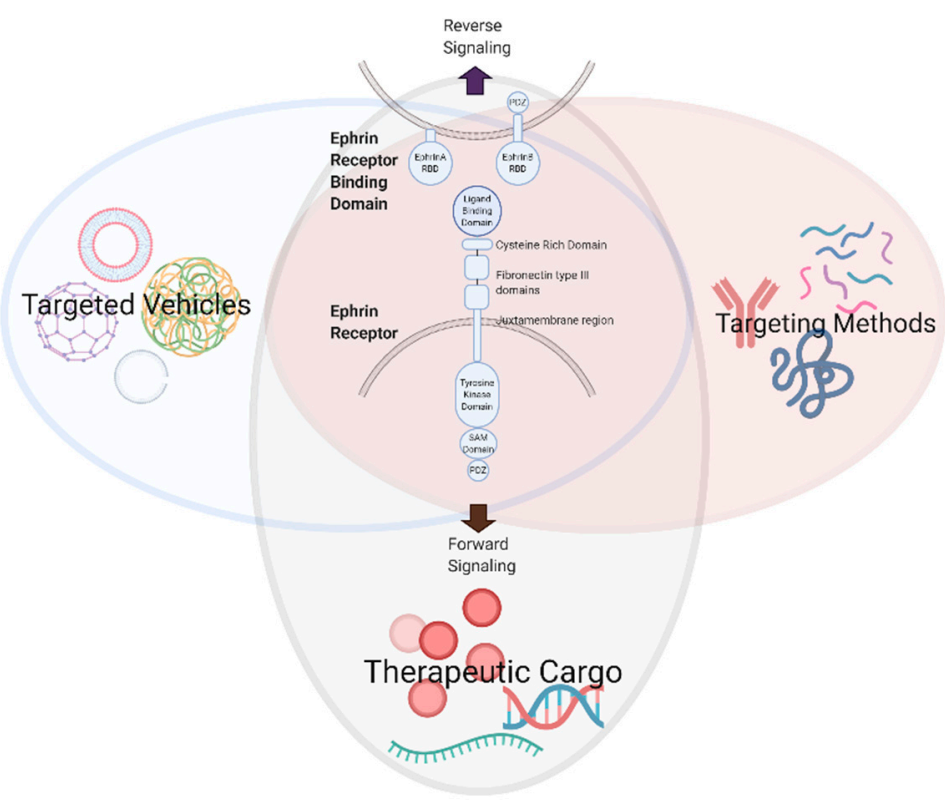

Figure 2. Development of therapeutic modalities to modulate Eph/ephrin signaling (created with BioRender.com).

\section{Eph/ephrin Signaling Dynamics}

Eph receptors and ephrin ligands are expressed in a variety of combinations and permutations in several cell types. These multi-domain proteins each contain several regions: the extracellular ligand-binding domain, a cysteine-rich domain, two fibronectin domains, FN1 and FN2, the cytoplasmic kinase domain, and the SAM domain $[11,12,17,65]$. These, in conjunction with aforementioned structural features, downstream effectors, termination by ADAMs (a disintegrin and metalloprotease), and recently discovered non-catalytic and reciprocal cross-regulatory activities, represent a treasure trove of targeting possibilities $[13,15]$. The following paragraphs discuss some of what is known about the role of Eph/ephrin signaling merely as an introduction to some common aspects of cellular function. Specifically, cell repulsion/adhesion, migration and proliferation, as drivers of inflammation as well as vascular and lymphatic function, are features of cells in nearly all organs (Figure 1B; $[6,66]$ ), and have broad applications in most disease processes.

Attenuation of inflammation and/or vascular permeability via Eph/ephrin signaling modulation significantly reduces tissue injury $[5,9,41,67]$. In the vascular endothelium and leukocytes, Eph/ephrin expression can be enhanced by pro-inflammatory cytokines, and can regulate local as well as systemic immune cell trafficking $[4,9,68,69]$. Ephrin-B2 and EphB4 are known to be expressed on the vascular endothelium and play a role in hematopoiesis and cell mobilization [70]. Luminal ephrinB1 and B2 expression are upregulated in endothelial cells, and interact with EphB2 on macrophages to promote transmigration [71]. Endothelial EphA2 is upregulated in response to TNF- $\alpha$ [72], and its activation enhances proinflammatory NF- $\mathrm{KB}$ and promotes disruption of the endothelial/epithelial barrier [5]. There is mounting evidence that both Eph receptors and ephrin ligands may also influence toll-like receptor function to propagate immune and/or tumorigenic signaling pathways, but more information about their prevalence and changes as an effect of disease on innate immune cells is needed [73]. EphA2, ephrin-A1 and ephrin-A2 are upregulated during monocyte differentiation [74] and, as inflammation 
progresses, leukocytic EphA1, EphA3 and EphA4 promote clustering of adhesion molecules and permit selective infiltration, resulting in adherence to endothelial cells and contributing to disruption of vascular integrity $[5,68]$. Cytoskeletal reorganization required for migration of $\mathrm{T}$ lymphocytes, widely recognized for their role in immune surveillance and initiation of the immune response, may be influenced by EphA/ephrin-A1 signaling, since T cells express Eph A1, A2, A3, A4, A7 and A8 [75,76]. Ephrin-A1 stimulation of $\mathrm{T}$ cells prevents chemotaxis, and thus ephrin-A1 may be a negative regulator of inflammation [77]. Sharfe et al. (2008) propose that ephrin-A1 enhances integrin-mediated adhesive interactions between $\mathrm{T}$ cells and endothelial cells, while EphA receptor activation on $\mathrm{T}$ cells inhibits it, so this would restrict $\mathrm{T}$ cell transmigration. Members of the EphB/ephrin-B family, integral mediators of vascular, lymphatic and neuronal development [78-80], also play a role in many of these disease processes, as observed by the involvement of EphB1 in microglial cells in models of nociceptive pain and inflammation [81], as well as splenic mononuclear EphB4-mediated inflammatory bowel disease [41]. Of course, expression of A and B receptors and ligands in any given cell within a tissue are not mutually exclusive, nor does their presence preclude the possibility for changes, in expression level and/or isoform, when that type of cell is detected in other tissue beds and/or exposed to various stimuli. For example, B cells in normal human peripheral blood express ephrinA4, EphA1-A4, EphA8, EphB2 and EphB4 while lymph node samples contain different amounts of ephrin-A4 and EphA1-A4 as well, but also ephrin-A1, ephrin-A3, ephrin-A5, EphA5, EphA10, ephrin-B2, EphB1 and EphB6; expression profiles that change significantly with disease progression [82]. $\mathrm{T}$ cells have also been shown to express EphB1, EphB2, EphB3, EphB6 and ephrinB1-B3, but whether there is co-expression on the same $\mathrm{T}$ cell and how they contribute to activation and/or differentiation are currently under investigation [9]. Adaptor proteins, a large group of accessory proteins containing protein-bind motifs, often have multiple binding units that enable them to join other proteins together to create a larger signaling complex. In particular, Src-like adaptor proteins (SLAPs), expressed primarily in the immune system, are involved in Eph RTK-mediated signal transduction by virtue of their interaction with several other adaptor/effector proteins, and the resultant activation or inhibition differentially influences tumorigenesis in a variety of tissues [83].

The role of Eph/ephrin signaling in the development of the lymphatic system has long been established. In contrast to the exclusive expression of ephrin-B2 and EphB4 in arteries and veins, respectively, an essential feature that drives boundary formation of these closely opposed systems [84], both ligand and receptor are expressed on lymphatic vessels [85]. Importantly, the PDZ domain (an initialism representing a common structural domain in signaling proteins that serves as an interface between the membrane and the cytoskeleton), but not the kinase domain, of the ephrin-B2 ligand is required for reverse signaling to promote normal lymphangiogenesis during development [86]. It is known that the lymphatic system, normally quiescent in an adult, is the biological vehicle for malignant metastasis [58] and, given the prominent role of Eph/ephrin RTKs in tumorigenesis and metastasis, their suitability as molecular targets is an active area of investigation that holds great promise [87]. Indeed, the potential utilization of Eph/ephrin signaling as prognostic indicators of disease progression or therapeutic targets, as in the correlation of EphB4/ephrin-B2 levels with the incidence of metastasis in breast cancer survivors [88], and the efficacy of targeting ephrin-B2 to limit tumor growth via attenuating adverse lymphangiogenesis and angiogenesis [89], are increasingly being recognized.

The importance of Eph/ephrin signaling during development underscores their relevance to stem cell plasticity, and they have been reported as determinants of cell fate in embryonic, mesenchymal and cord blood stem cells. As previously discussed, Eph/ephrin signaling participates in hematopoiesis and related malignancies. Mesenchymal stems from bone marrow and adipose tissue express several members of both the A and B families, which regulate survival and renewal, differentiation, morphology, mobilization, homing and engraftment [90-92]. In embryonic stem cells, a phosphoproteomic study revealed that the EphA2 receptor was reported to be a critical target of FGF4, leading to disabling of the EphA2 receptor via ERK1/2 and ser/thr phosphorylation and concomitant transcription of ephrin ligands, 
resulting in exit from the pluripotent compartment to initiate differentiation [93]. Reprogramming of adult somatic stem cells is effected by secreted, truncated EphA7-induced attenuation of ERK1/2 signaling [94]. Oleic acid, a naturally occurring mono-unsaturated fatty acid, increased EphB2 expression in cord blood-derived mesenchymal stem cells, thereby enhancing their migratory capacity by increasing F-actin formation which alters the cytoskeleton [95]. Several members of the Eph/ephrin RTK family contribute to blastocyst implantation and invasion, as well as modulation of immunity during placentation [96]. The complex nature of Eph/ephrin signaling in these stem cell populations, as a function of space and time, warrants systematic characterization in order to fully appreciate their role in development and disease.

The Eph/ephrin RTKs clearly exert a prominent influence on cytoskeletal reorganization, which regulates cellular adhesion/repulsion/tensity, key elements of morphologic changes in metastasis and pathologic angiogenesis, [97,98] as well as modulation of inflammatory cell motility [99,100]. Reverse signaling through ephrinB1, resulting in tyrosine phosphorylation, recruits SH2/SH3 domain adaptor protein Grb4 binds and subsequently activates FAK, Cbl, Abl, paxillin and others to modulate cytoskeletal dynamics [101,102]. Forward signaling via autophosphorylated EphB2 and concomitant recruitment of myosin $1 \mathrm{~b}$ regulates cytoskeletal remodeling [102,103]. EphA1/Ephrin-A1 activation attenuates RhoA/ROCK (Rho-associated coiled-coil containing protein kinase) to modify the cytoskeleton, and thus influences morphology and motility in HEK293 cells [104]. Shp2 regulates dephosphorylation of ROCKII, and adds an additional level of control to RhoA-dependent activation and mediation of contractile forces [105], and Shp2 is recruited by ephrin-A1-EphA2 leading to suppression of integrin function and FAK inactivation, which has strong implications for inflammation and wound-healing processes [106]. Other aspects of wound-healing, such as Ca2+ handling [107], mitochondrial fission [108], ATP generation [109], apoptosis [8,110], autophagy and fibrosis [111], are also influenced by this system, and there may well be others as yet undiscovered. Intracellular post-translational signaling cascades and transcriptional modifications can also be affected, but the mediators involved in transmitting these signals are, as yet, unclear. To complicate matters, cancer progression associated with an Eph receptor can be paradoxically up- or down-regulated in a tissue-specific manner [7]. Moreover, post-translational modifications can govern subcellular localization, conformation and clustering, which will directly influence activity, a feature which may be manipulated for therapeutic advantage. For example, the pharmacodynamics of EphA4-Fc (a chimeric protein fused with the Fc constant region of immunoglobulin heavy-chain) were substantially enhanced by glycosylation [112]. Scheideler et al. (2020) have developed a novel high-throughput DNA-based patterning platform, using multilayer lithography to recreate the complex spatial signaling systems between cells and tissues, that will accelerate our understanding of how these signals cumulatively govern cell behavior [113]. Much more research is needed to delineate the diverse roles of this system in a cell- and tissue-specific manner, as well as its systemic interplay under normal as well as pathological conditions.

\section{Small Molecule, Peptide, Protein and RNA Targeting of Ephrins}

Advancements in the automated manufacturing and screening of small molecules with increased potency and specificity are anticipated to accelerate the identification of viable targets and yield promising therapeutic candidates. While screening of small molecule libraries remains a productive strategy for the identification of novel Eph agonists and antagonists, design strategies that link therapeutic small molecules together, or link them with Eph-targeting peptides, proteins, and antibodies, have emerged as viable strategies for the creation of multi-modal therapeutics. While these next generation therapeutics hold great promise, eventually they must be adequately vetted to ensure safety and efficacy before heading to the clinic. As a result, significant delays can be anticipated before the promise of many of these exciting strategies is fully realized.

The past decade of small molecule-based Eph targeting has been fruitful, with the identification of numerous small molecules and peptides that enable specific targeting of Eph receptors (see summary, 
Table 1) [17,114]. In addition, Ephrin-targeting peptide sequences have been identified and further modified to improve specificity and bioavailability. In a recent report, the crystal structures of engineered variants of the EphA2-targeting peptide YSA with the EphA2 ligand binding domain were reported, providing an experimental framework for improving the affinity of EphA2-targeting peptides from the micromolar domain to the nanomolar domain and beyond [115]. Moreover, a new $\mathrm{pH}$-dependent membrane peptide (TYPE7) was created based on the transmembrane domain sequence of EphA2 [116]. This peptide undergoes $\mathrm{pH}$-dependent membrane insertion, and has an EphA2-targeting profile like that of ephrin-A1. Novel peptides with an affinity for the EphA2 receptor (peptide 135 H11, an optimized variant of YSA-derived peptide 123B9 [117]) and the EphA4 receptor (peptide 123C4, [118]) have also been investigated as potential pancreatic cancer treatments and therapeutics for amylotrophic lateral sclerosis (ALS). Small molecules have been extensively investigated for Eph receptor-mediated therapeutic potential, via screens of libraries of kinase inhibitors [119] and ATP-competitive inhibitors [120]. Structure-activity relationships and bioavailability studies for novel antagonists of EphA1 and EphB1 have also been reported [121]. The small molecule UniPR500, an EphA5 inhibitor, has undergone evaluation for its ability to improve glucose homeostasis in diabetic mice [122]. A novel EphB2-targeting molecule, HMQ-T-B10, was investigated as a potential anti-tumor therapeutic in hepatocellular carcinoma [123]. The EphB2-targeting properties of berberine have also been explored for anti-cancer activity, both alone [124] and in combination with the novel small molecule TPD7 [125]. Of further note, numerous peptide/protein/antibody-small molecule conjugates have been investigated for their ability to simultaneously target (peptide/protein/antibody) and treat (small molecule) conditions mediated by Eph receptors [126]. For example, the fusion of EphA2-targeting peptides and paclitaxel has been an active area of investigation [127-130], in addition to a fusion of gemcitabine and an EphA2 peptide targeted to pancreatic cancer [131]. EphA2-targeted antibody-drug conjugates have also been evaluated for their ability to target and treat tumors [132], and anti-EphA4 antibodies conjugated to the DNA-damaging reagent calicheamicin have been used in vivo to target tumor-initiating cells in triple-negative breast cancer and ovarian cancer [133]. Recently, Eph-targeted therapeutic strategies have also embraced therapeutic proteins, as radiosensitizers in cancer treatment (sEphB4-HAS, [134]) and as Eph-targeted cytotoxins (eA5-PE38QQR, [135]). A bispecific antibody, targeting both EphA2 and EphA3, has been explored as a potential therapy for glioblastoma [136], while antibodies targeted to EphB4 have been investigated for anti-cancer activity [137]. Finally, numerous RNA-based strategies have been explored for targeting Eph receptors [138]. Recent efforts include the synergistic knockdown of EphB2 with siRNA coupled with radiotherapy [139], and the targeting of EphA2 with microRNAs [140,141].

Table 1. Peptides, proteins, and small molecules developed to target Eph Receptors.

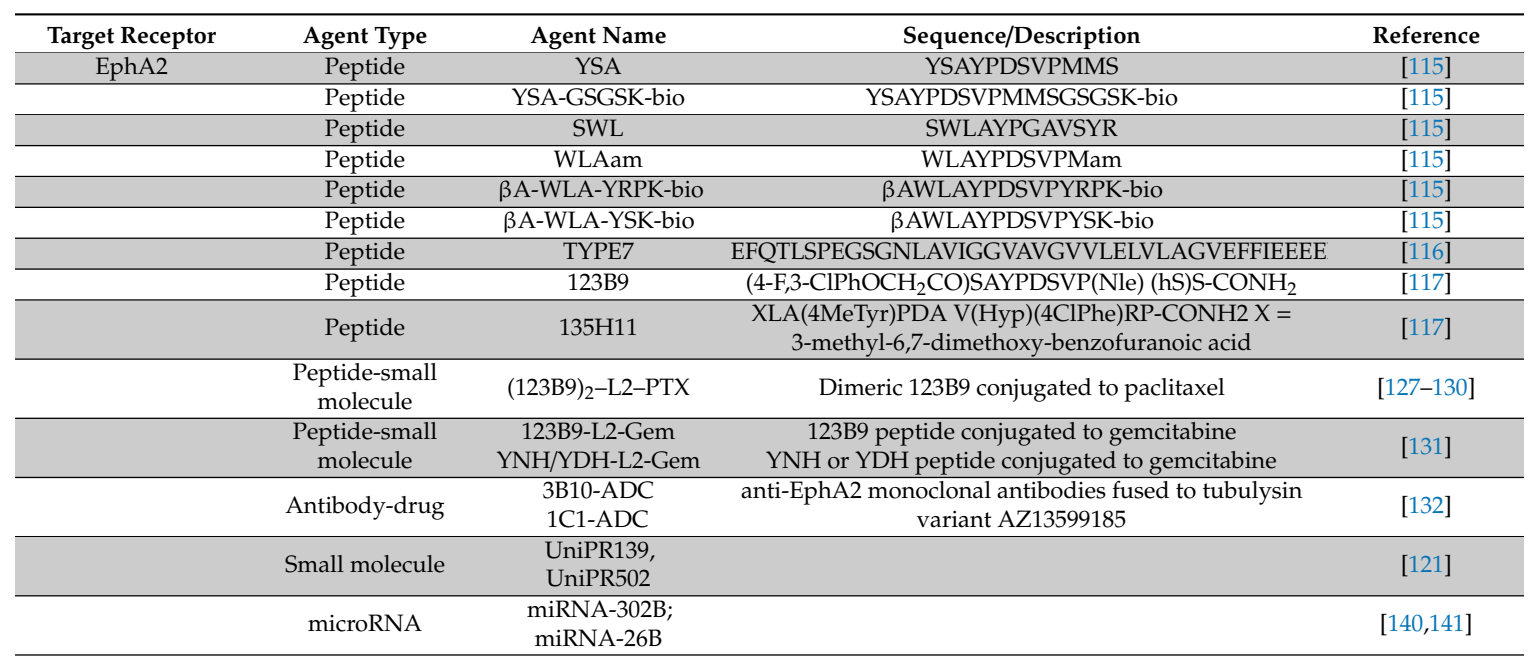


Table 1. Cont

\begin{tabular}{|c|c|c|c|c|}
\hline Target Receptor & Agent Type & Agent Name & Sequence/Description & Reference \\
\hline EphA4 & Peptide & $123 \mathrm{C} 4$ & & [118] \\
\hline EphA5 & Small molecule & UniPR500 & & [122] \\
\hline \multirow{3}{*}{ EphB2 } & Small molecule & berberine & & [124] \\
\hline & Small molecule & TPD7 & & [125] \\
\hline & siRNA & & EphB2 knockdown + radiation & [139] \\
\hline \multirow[t]{2}{*}{$\begin{array}{l}\text { Multiple } \\
\text { targets }\end{array}$} & Protein fusion & eA5-PE38QQR & $\begin{array}{c}\text { EphR ligand eA5 fused to truncated form of } \\
\text { Pseudomonas aeruginosa exotoxin A }\end{array}$ & [135] \\
\hline & Antibody & EPHA2/A3 BsAb & Novel bispecific antibody targeting EphA2 and EphA3 & [136] \\
\hline
\end{tabular}

\section{Targeted Delivery Strategies for Ephrins}

Targeted smart drug delivery strategies to provide specific, rapid, non-invasive, biocompatible and robust Eph/ephrin RTK signaling benefits to the cell/tissue or region of interest, while avoiding off-target and/or toxic effects, are actively being pursued. For example, liposomes, microspheres, gels and biodegradable polymer nanoparticles are being engineered to replace conventional formulations and administration methods, and have demonstrated early success, particularly in cancer therapy (see summary Table 2) [142-145].

Table 2. Engineered delivery systems designed to improve target specificity.

\begin{tabular}{cccc}
\hline Target Receptor & Agent Type & Description & Reference \\
\hline EphA2 & Liposome & YSA-liposomes for co-delivery of doxorubicin and JIP1 siRNA & {$[146]$} \\
\hline EphA10 & Liposome & $\begin{array}{c}\text { EphA10 antibody lipoplex for co-delivery of doxorubicin and } \\
\text { MDR1-siRNA }\end{array}$ & {$[147]$} \\
\hline EphA2 & Liposome & YSA-liposomes for delivery of doxorubicin & {$[148]$} \\
\hline EphA2 & Liposome & Eph1A-liposomes for delivery of let-7a miRNA & {$[149]$} \\
\hline EphA2 & Liposome & Delivery of paclitaxel and docetaxel prodrugs & {$[150]$} \\
\hline EphA2 & Lipsome & scFv-liposome for delivery of cytotoxin & {$[151,152]$} \\
\hline EphA2 & Polymer & scFV 4B3-pegylated hyperbranched polymer & {$[153]$} \\
\hline $\begin{array}{c}\text { Multiple } \\
\text { targets }\end{array}$ & Polymer & $\begin{array}{c}\text { CHVLWSTRC-peptide labeled cationic polymer delivers } \\
\text { therapeutic sRAE-1 } \gamma \text { plasmid via EphA2 and EphA4 receptors }\end{array}$ & {$[154]$} \\
\hline EphB4 & Polymer & Biopolymer functionalized with ectodomain of ephrinB2 & {$[155]$} \\
\hline EphA2 & DNA & Ephrin-A1 decorated DNA nanostructure & {$[156]$} \\
\hline EphA2 & Nanoparticle & Pegylated EphA2 peptide coated nanoparticles & {$[157]$} \\
\hline EphA2 & Nanoparticle & YSA-nanoparticle for co-delivery of ILsi RNA and paclitaxel & {$[158]$} \\
\hline EphA2 & Nanorod & YSA-gold nanorods & {$[159]$} \\
\hline EphB1 & Nanoparticle & EphB1 ligand binding domain-erythrocyte nanoparticles for & {$[160]$} \\
\hline EphA3 & Nanoparticle & EphA3 antibody-nanoparticles for delivery of temozolomide & {$[161]$} \\
\hline EphA2 & Nanoparticle & YSA-polymeric nanoparticles & {$[162]$} \\
\hline EphA2 & Nanoparticle & Chitosan-coated Ephrin-A1-PE38/GM-CSF nanoparticles & {$[163]$} \\
\hline
\end{tabular}

Eph-targeted liposomes have been formulated for the delivery of multiple therapeutic cargoes, including small molecule therapeutics, miRNAs, siRNAs and gene therapies. Efforts to target liposomes to Eph receptors include the EphA2-targeted delivery of doxorubicin and siRNA from nanoliposomes [146], EphA10-targeted delivery of doxorubicin and siRNA from lipoplexes [147], and EphA2-targeted delivery of doxorubicin from liposomes [148]. Nanoliposome formulations targeted to EphA2 have also been used to deliver a therapeutic microRNA (let-7a) to lung cancer cells, significantly increasing the delivery over treatment with miRNA alone [149]. Recently, an EphA2-targeting liposome encapsulating a taxane-prodrug was developed and tested for efficacy in lung and breast cancer models [150], with the targeted liposome formulation possessing higher efficacy than delivery of the drug alone. Nanoliposomes have also been linked to Eph-targeted single 
chain variable fragment (scFv) antibodies as a potential mode of therapeutic delivery. For example, targeted delivery of a liposomal cytotoxic nanoparticle was enabled by coupling with an engineered anti-EphA2 scFv [151,152]. In recent years, polymeric scaffolds have also been exploited for numerous Eph-targeting applications. These include the use of antibody-labeled PEG-ylated polymers for targeting the EphA2 receptor [153], and peptide-labeled cationic polymers targeted to EphA2 and EphA4 for therapeutic gene delivery [154]. EphB4-targeting biopolymer scaffolds have also been developed for the induction of the differentiation of neural stem cells [155]. Interestingly, DNA has been functionalized with the EphA2-targeting peptide SWL to create DNA-SWL nanostructures [156]. These nanostructures were shown to target EphA2-expressing prostate cancer cells.

Numerous nanoparticle-based formulations have been designed for the targeting of ephrins and Eph signaling pathways. For example, peptide-coated nanoparticles have also been targeted to EphA2 for the delivery of anti-cancer compounds [157]. Recently, a multi-faceted, EphA2-targeted, black phosphorous-based nanosystem was reported [158]. This nanoformulation uses the YSA peptide for EphA2-targeting and carries two therapeutic moieties: siRNA (interleukin-1alpha silencing) and the small molecule paclitaxel. In another report, the YSA peptide was used to functionalize gold nanorods, resulting in anti-proliferative activity on prostate cancer cells [159]. Eph-targeted nanoparticle formulations can also be the basis for advanced theranostic applications. For example, erythrocyte-derived nanoparticles were targeted to ephrin-B2 ligands via functionalization with the ligand binding domain of EphB1 [160]. Inclusion of a NIR-active dye (near infrared) in the nanoformulation makes them a promising platform for long wavelength phototherapies targeted to diseased cell populations. Ephrin-targeted nanoparticles have been developed to target glioblastoma. In one recent study, antibody-labelled polylactide-co-glycolide (PLGA) nanoparticles, targeting EphA3, were used for delivery of temozolomide via a nose-to-brain delivery route [161]. PLGA nanoparticles have also been targeted to the EphA2 receptor by functionalization with the YSA peptide, and their uptake in bleomycin-damaged lungs and cells investigated as a potential route for therapeutic delivery [162]. Nanoparticles have also been used to deliver novel recombinant proteins. For example, chitosan-coated nanoparticles bearing the recombinant protein Ephrin-A1-PE38/GM-CF were demonstrated to have anti-tumor activity in rats [163].

Finally, exosomes have been identified as a potentially powerful strategy for using Eph/ephrins to target select populations of cells and neurons [164]. Exosomes displaying membrane-bound Eph receptors were recently demonstrated to facilitate cell-contact-independent communication between cells $[165,166]$. As exosomes also have the capability of transporting therapeutic genes, proteins, and small molecules, they comprise another important class of Ephrin-targeted drug delivery that warrants further investigation. Exosomes have also been shown to promote angiogenesis through transport of Eph receptors [167]. Targeting or harnessing the intrinsic properties of EphR-laden exosomes may present a novel therapeutic route for inhibiting angiogenesis in cancer [168]. Exosomes may also transmit chemoresistance via delivery of EphA2 [169]. In this regard, targeting exosomal EphR could be a novel route for inhibiting chemoresistance. Finally, exosomes from cancer cells are known to transfer miRNAs to other cells within tumors [170]. This suggests that exosomes could perhaps be hijacked to deliver therapeutic small RNAs as well [171]. For example, exosomes from human cardiac progenitor cells have been shown to improve cardiac function and reduce apoptosis after myocardial infarction, through the transfer of microRNAs in infarcted hearts [172].

\section{Conclusions}

The intricate, multifaceted, and pervasive nature of the Eph/ephrin RTK system is being meticulously studied using an assortment of sophisticated molecular, cellular and in vivo techniques. These highly conserved proteins are a new and rapidly growing area of research as they influence a range of cellular behaviors and biological processes, thus possessing enormous translational potential for the treatment of human diseases. Currently, there are several clinical trials at different stages of recruitment/completion in a broad range of cancers. Many unanswered questions remain concerning 
the relative influence of these signaling pathways, not only on each other but on other mediators within the cell, as well as their interactions with neighboring cells, and the timing and cumulative/synergistic consequences of these events present a daunting challenge for discovering solutions. However, this versatility also holds great promise for the future of personalized medicine.

Author Contributions: Both authors contributed equally to this manuscript. All authors have read and agreed to the published version of the manuscript.

Funding: This research was funded by a collaborative Brody Brothers Endowment grant awarded to Hughes and Virag. Virag has also been funded by the North Carolina Biotechnology Center (Biotechnology Research Grant and an Institutional Research Grant) as well as the NHLBI (R15, 1RH15HL124483-01A1), all of which have provided support for the basic research referenced in this review.

Acknowledgments: The authors would like to acknowledge the Departments of Chemistry and Physiology, Brody School of Medicine at East Carolina University for their support in this collaborative endeavor.

Conflicts of Interest: The authors declare no conflicts of interest.

\section{References}

1. Arvanitis, D.; Davy, A. Eph/ephrin signaling networks. Genome Res. 2008, 22, 416-429. [CrossRef] [PubMed]

2. Davy, A.; Soriano, P. Ephrin signaling in vivo: Look both ways. Dev. Dyn. 2004, 232, 1-10. [CrossRef] [PubMed]

3. Niethamer, T.K.; Bush, J.O. Getting direction(s): The Eph/ephrin signaling system in cell positioning. Dev. Boil. 2019, 447, 42-57. [CrossRef] [PubMed]

4. Coulthard, M.; Morgan, M.; Woodruff, T.M.; Arumugam, T.V.; Taylor, S.M.; Carpenter, T.C.; Lackmann, M.; Boyd, A.W. Eph/Ephrin Signaling in Injury, and Inflammation. Am. J. Pathol. 2012, 181, 1493-1503. [CrossRef] [PubMed]

5. Funk, S.; Orr, A.W. Ephs and ephrins resurface in inflammation, immunity, and atherosclerosis. Pharmacol. Res. 2013, 67, 42-52. [CrossRef] [PubMed]

6. Kania, A.; Klein, R. Mechanisms of ephrin-Eph signalling in development, physiology, and disease. Nat. Rev. Mol. Cell Boil. 2016, 17, 240-256. [CrossRef]

7. Kou, C.-T.J.; Kandpal, R.P. Differential Expression Patterns of Eph Receptors and Ephrin Ligands in Human Cancers. BioMed Res. Int. 2018, 2018, 1-23. [CrossRef]

8. Zhou, H.; Sun, Y.; Zhang, L.; Kang, W.; Li, N.; Li, Y. The RhoA/ROCK pathway mediates high glucose-induced cardiomyocyte apoptosis via oxidative stress, JNK, and p38MAPK pathways. Diabetes Metab. Res. Rev. 2018, 34, e3022. [CrossRef]

9. Darling, T.K.; Lamb, T.J. Emerging Roles for Eph Receptors and Ephrin Ligands in Immunity. Front. Immunol. 2019, 10, 1473. [CrossRef]

10. Wu, B.; Rockel, J.S.; Lagares, D.; Kapoor, M. Ephrins and Eph Receptor Signaling in Tissue Repair and Fibrosis. Curr. Rheumatol. Rep. 2019, 21, 23. [CrossRef]

11. Barquilla, A.; Pasquale, E.B. Eph receptors and ephrins: Therapeutic opportunities. Annu. Rev. Pharmacol. Toxicol. 2014, 55, 465-487. [CrossRef] [PubMed]

12. Himanen, J.P.; Yermekbayeva, L.; Janes, P.W.; Walker, J.R.; Xu, K.; Atapattu, L.; Rajashankar, K.R.; Mensinga, A.; Lackmann, M.; Nikolov, D.B.; et al. Architecture of Eph receptor clusters. Proc. Natl. Acad. Sci. USA 2010, 107, 10860-10865. [CrossRef] [PubMed]

13. Saha, N.; Robev, D.; Mason, E.; Himanen, J.; Nikolov, D.B. Therapeutic potential of targeting the Eph/ephrin signaling complex. Int. J. Biochem. Cell Boil. 2018, 105, 123-133. [CrossRef] [PubMed]

14. Tognolini, M.; Hassan-Mohamed, I.; Giorgio, C.; Zanotti, I.; Lodola, A. Therapeutic perspectives of Eph-ephrin system modulation. Drug Discov. Today 2014, 19, 661-669. [CrossRef] [PubMed]

15. Liang, L.-Y.; Patel, O.; Janes, P.W.; Murphy, J.M.; Lucet, I.S. Eph receptor signalling: From catalytic to non-catalytic functions. Oncogene 2019, 38, 6567-6584. [CrossRef] [PubMed]

16. Pasquale, E.B. Eph receptors and ephrins engage in cellular cannibalism. J. Cell Boil. 2019, 218, 3168-3170. [CrossRef] [PubMed]

17. Boyd, A.W.; Bartlett, P.F.; Lackmann, M. Therapeutic targeting of EPH receptors and their ligands. Nat. Rev. Drug Discov. 2013, 13, 39-62. [CrossRef] 
18. Hirai, H.; Maru, Y.; Hagiwara, K.; Nishida, J.; Takaku, F. A novel putative tyrosine kinase receptor encoded by the eph gene. Science 1987, 238, 1717-1720. [CrossRef]

19. Halloran, M.C.; A Wolman, M. Repulsion, or adhesion: Receptors make the call. Curr. Opin. Cell Boil. 2006, 18, 533-540. [CrossRef]

20. Hamada, K.; Oike, Y.; Ito, Y.; Maekawa, H.; Miyata, K.; Shimomura, T.; Suda, T. Distinct Roles of Ephrin-B2 Forward and EphB4 Reverse Signaling in Endothelial Cells. Arter. Thromb. Vasc. Boil. 2003, 23, 190-197. [CrossRef]

21. Pasquale, E.B. The Eph family of receptors. Curr. Opin. Cell Boil. 1997, 9, 608-615. [CrossRef]

22. Zhou, R. The Eph Family Receptors and Ligands. Pharmacol. Ther. 1998, 77, 151-181. [CrossRef]

23. Pasquale, E.B. Eph receptor signalling casts a wide net on cell behaviour. Nat. Rev. Mol. Cell Boil. 2005, 6, 462-475. [CrossRef] [PubMed]

24. Pasquale, E.B. Eph-Ephrin Bidirectional Signaling in Physiology and Disease. Cell 2008, 133, 38-52. [CrossRef]

25. Ojosnegros, S.; Cutrale, F.; Rodríguez, D.; Otterstrom, J.; Chiu, C.L.; Hortigüela, V.; Tarantino, C.; Seriola, A.; Mieruszynski, S.; Martinez, E.; et al. Eph-ephrin signaling modulated by polymerization and condensation of receptors. Proc. Natl. Acad. Sci. USA 2017, 114, 13188-13193. [CrossRef]

26. Rozbesky, D.; Jones, E.Y. Cell guidance ligands, receptors, and complexes, orchestrating signalling in time and space. Curr. Opin. Struct. Boil. 2020, 61, 79-85. [CrossRef]

27. Seiradake, E.; Harlos, K.; Sutton, G.; Aricescu, A.R.; Jones, E.Y. An extracellular steric seeding mechanism for Eph-ephrin signaling platform assembly. Nat. Struct. Mol. Boil. 2010, 17, 398-402. [CrossRef]

28. Wang, Y.; Shang, Y.; Li, J.; Chen, W.; Li, G.; Wan, J.; Liu, W.; Zhang, M. Specific Eph receptor-cytoplasmic effector signaling mediated by SAM-SAM domain interactions. eLife 2018, 7, e35677. [CrossRef]

29. Mollinedo, F.; Gajate, C. Lipid rafts as signaling hubs in cancer cell survival/death and invasion: Implications in tumor progression and therapy. J. Lipid Res. 2020. [CrossRef]

30. Chavent, M.; Seiradake, E.; Jones, E.Y.; Sansom, M.S. Structures of the EphA2 Receptor at the Membrane: Role of Lipid Interactions. Structure 2015, 24, 337-347. [CrossRef]

31. Sakamoto, A.; Sugamoto, Y.; Tokunaga, Y.; Yoshimuta, T.; Hayashi, K.; Konno, T.; Kawashiri, M.; Takeda, Y.; Yamagishi, M. Expression Profiling of the Ephrin (EFN) and Eph Receptor (EPH) Family of Genes in Atherosclerosis-Related Human Cells. J. Int. Med. Res. 2011, 39, 522-527. [CrossRef] [PubMed]

32. Jellinghaus, S.; Poitz, D.M.; Ende, G.; Augstein, A.; Weinert, S.; Stutz, B.; Braun-Dullaeus, R.C.; Pasquale, E.B.; Strasser, R.H. Ephrin-A1/EphA4-mediated adhesion of monocytes to endothelial cells. Biochim. Biophys. Acta 2013, 1833, 2201-2211. [CrossRef] [PubMed]

33. Sheleg, M.; Yu, Q.; Go, C.; Wagner, G.C.; Kusnecov, A.W.; Zhou, R. Decreased maternal behavior and anxiety in ephrin-A5(-/-) mice. Genes. Brain Behav. 2017, 16, 271-284. [CrossRef] [PubMed]

34. Sheleg, M.; Yochum, C.L.; Richardson, J.; Wagner, G.C.; Zhou, R. Ephrin-A5 regulates inter-male aggression in mice. Behav. Brain Res. 2015, 286, 300-307. [CrossRef]

35. Gamble, J.A.; Karunadasa, D.K.; Pape, J.-R.; Skynner, M.J.; Todman, M.G.; Bicknell, R.J.; Allen, J.P.; Herbison, A.E. Disruption of Ephrin Signaling Associates with Disordered Axophilic Migration of the Gonadotropin-Releasing Hormone Neurons. J. Neurosci. 2005, 25, 3142-3150. [CrossRef]

36. Cisse, M.; Checler, F. Eph receptors: New players in Alzheimer's disease pathogenesis. Neurobiol. Dis. 2015, 73, 137-149. [CrossRef]

37. Dines, M.; Grinberg, S.; Vassiliev, M.; Ram, A.; Tamir, T.; Lamprecht, R. The roles of Eph receptors in contextual fear conditioning memory formation. Neurobiol. Learn. Mem. 2015, 124, 62-70. [CrossRef]

38. Jain, R.; Jain, D.; Liu, Q.; Bartosinska, B.; Wang, J.; Schumann, D.M.; Kauschke, S.G.; Eickelmann, P.; Piemonti, L.; Gray, N.S.; et al. Pharmacological inhibition of Eph receptors enhances glucose-stimulated insulin secretion from mouse and human pancreatic islets. Diabetologyia 2013, 56, 1350-1355. [CrossRef]

39. Weiss, A.-C.; Kispert, A. Eph/ephrin signaling in the kidney and lower urinary tract. Pediatr. Nephrol. 2015, 31, 359-371. [CrossRef]

40. Yucel, S.; Dravis, C.; Garcia, N.; Henkemeyer, M.; Baker, L.A. Hypospadias and anorectal malformations mediated by defective Eph/ephrin signaling. J. Pediatr. Urol. 2007, 3, 354-363. [CrossRef]

41. Grandi, A.; Zini, I.; Palese, S.; Giorgio, C.; Tognolini, M.; Marchesani, F.; Bruno, S.; Flammini, L.; Cantoni, A.M.; Castelli, R.; et al. Targeting the Eph/Ephrin System as Anti-Inflammatory Strategy in IBD. Front. Pharmacol. 2019, 10, 691. [CrossRef] [PubMed] 
42. Lindsey, R.C.; Rundle, C.H.; Mohan, S. Role of IGF1 and EFN-EPH signaling in skeletal metabolism. J. Mol. Endocrinol. 2018, 61, 87-102. [CrossRef] [PubMed]

43. Fawal, M.-A.; Jungas, T.; Kischel, A.; Audouard, C.; Iacovoni, J.S.; Davy, A. Cross Talk between One-Carbon Metabolism, Eph Signaling, and Histone Methylation Promotes Neural Stem Cell Differentiation. Cell Rep. 2018, 23, 2864-2873. [CrossRef] [PubMed]

44. Stark, D.A.; Karvas, R.M.; Siegel, A.L.; Cornelison, D. Eph/ephrin interactions modulate muscle satellite cell motility and patterning. Development 2011, 138, 5279-5289. [CrossRef]

45. Lai, K.-O.; Ip, F.C.; Cheung, J.; Fu, K.Y.; Ip, N.Y. Expression of Eph Receptors in Skeletal Muscle and Their Localization at the Neuromuscular Junction. Mol. Cell. Neurosci. 2001, 17, 1034-1047. [CrossRef] [PubMed]

46. Dries, J.L.; Kent, S.D.; Virag, J.A. Intramyocardial administration of chimeric ephrinA1-Fc promotes tissue salvage following myocardial infarction in mice. J. Physiol. 2011, 589, 1725-1740. [CrossRef] [PubMed]

47. Dusablon, A.; Kent, S.; Coburn, A.; Virag, J.A. EphA2-receptor deficiency exacerbates myocardial infarction and reduces survival in hyperglycemic mice. Cardiovasc. Diabetol. 2014, 13, 114. [CrossRef]

48. O’Neal, W.T.; Griffin, W.F.; Kent, S.D.; Faiz, F.; Hodges, J.; Vuncannon, J.; Virag, J.A. Deletion of the EphA2 receptor exacerbates myocardial injury and the progression of ischemic cardiomyopathy. Front. Physiol. 2014, 5. [CrossRef]

49. Dusablon, A.; Parks, J.; Whitehurst, K.; Estes, H.; Chase, R.; Vlahos, E.; Sharma, U.; Wert, D.; Virag, J.A. EphrinA1-Fc attenuates myocardial ischemia/reperfusion injury in mice. PLoS ONE 2017, 12, e0189307. [CrossRef]

50. Lefcoski, S.; Kew, K.; Reece, S.; Torres, M.J.; Parks, J.; Reece, S.; Bras, L.E.D.C.; Virag, J.A. Anatomical-Molecular Distribution of EphrinA1 in Infarcted Mouse Heart Using MALDI Mass Spectrometry Imaging. J. Am. Soc. Mass Spectrom. 2018, 29, 527-534. [CrossRef]

51. Horton, J.L.; Virag, J.A. Use of Multifactorial Treatments to Address the Challenge of Translating Experimental Myocardial Infarct Reduction Strategies. Int. J. Mol. Sci. 2019, 20, 1449. [CrossRef] [PubMed]

52. Torres, M.J.; McLaughlin, K.L.; Renegar, R.H.; Valsaraj, S.; Whitehurst, K.S.; Sharaf, O.M.; Sharma, U.M.; Horton, J.L.; Sarathy, B.; Parks, J.C.; et al. Intracardiac administration of ephrinA1-Fc preserves mitochondrial bioenergetics during acute ischemia/reperfusion injury. Life Sci. 2019, 239, 117053. [CrossRef] [PubMed]

53. Baldwin, C.; Chen, Z.W.; Bedirian, A.; Yokota, N.; Nasr, S.H.; Rabb, H.; Lemay, S. Upregulation of EphA2 during in vivo and in vitro renal ischemia-reperfusion injury: Role of Src kinases. Am. J. Physiol. Physiol. 2006, 291, 960-971. [CrossRef] [PubMed]

54. Basile, D.P.; Yoder, M.C. Getting the "inside" scoop on ephrinB2 signaling in pericytes and the effect on peritubular capillary stability. J. Am. Soc. Nephrol. 2013, 24, 521-523. [CrossRef]

55. Ernst, A.-S.; Böhler, L.-I.; Hagenston, A.M.; Hoffmann, A.; Heiland, S.; Sticht, C.; Bendszus, M.; Hecker, M.; Bading, H.; Marti, H.H.; et al. EphB2-dependent signaling promotes neuronal excitotoxicity and inflammation in the acute phase of ischemic stroke. Acta Neuropathol. Commun. 2019, 7, 15. [CrossRef]

56. Ghori, A.; Freimann, F.B.; Nieminen-Kelhä, M.; Kremenetskaia, I.; Gertz, K.; Endres, M.; Vajkoczy, P.; Nieminen-Kehlä, M. EphrinB2 Activation Enhances Vascular Repair Mechanisms and Reduces Brain Swelling After Mild Cerebral Ischemia. Arter. Thromb. Vasc. Boil. 2017, 37, 867-878. [CrossRef]

57. Zhou, X.; Tu, P.; Chen, X.; Guo, S.; Wang, J. Eph Receptors: Actors in Tumor Microenvironment. Crit. Rev. Oncog. 2017, 22, 499-505. [CrossRef]

58. Farnsworth, R.H.; Achen, M.G.; Stacker, S.A. The evolving role of lymphatics in cancer metastasis. Curr. Opin. Immunol. 2018, 53, 64-73. [CrossRef]

59. Buensuceso, A.V.; Son, A.I.; Zhou, R.; Paquet, M.; Withers, B.M.; de Roo, B.J. Ephrin-A5 is required for optimal fertility and a complete ovulatory response to gonadotropins in the female mouse. Endocrinology 2016, 157, 942-955. [CrossRef]

60. Wang, W.; Feng, L.; Zhang, H.; Hachy, S.; Satohisa, S.; Laurent, L.C.; Parast, M.; Zheng, J.; Chen, N.-B. Preeclampsia up-regulates angiogenesis-associated microRNA (i.e., miR-17, -20a, and -20b) that target ephrin-B2 and EPHB4 in human placenta. J. Clin. Endocrinol. Metab. 2012, 97, 1051-1059. [CrossRef]

61. Aasheim, H.-C.; Patzke, S.; Hjorthaug, H.S.; Finne, E.F. Characterization of a novel Eph receptor tyrosine kinase, EphA10, expressed in testis. Biochim. Biophys. Acta Gen. Subj. 2005, 1723, 1-7. [CrossRef] [PubMed]

62. Gofur, M.R.; Ogawa, K. Compartments with predominant ephrin-B1 and EphB2/B4 expression are present alternately along the excurrent duct system in the adult mouse testis and epididymis. Andrology 2019, 7, 888-901. [CrossRef] [PubMed] 
63. Kida, Y.; Ieronimakis, N.; Schrimpf, C.; Reyes, M.; Duffield, J.S. EphrinB2 Reverse Signaling Protects against Capillary Rarefaction and Fibrosis after Kidney Injury. J. Am. Soc. Nephrol. 2013, 24, 559-572. [CrossRef] [PubMed]

64. Wang, J.; Zheng, X.; Peng, Q.; Zhang, X.; Qin, Z. Eph receptors: The bridge linking host and virus. Cell. Mol. Life Sci. 2019, 1-11. [CrossRef]

65. Wang, Y.; Li, Q.; Zheng, Y.; Li, G.; Liu, W. Systematic biochemical characterization of the SAM domains in Eph receptor family from Mus Musculus. Biochem. Biophys. Res. Commun. 2016, 473, 1281-1287. [CrossRef]

66. Hafner, C.; Schmitz, G.; Meyer, S.; Bataille, F.; Hau, P.; Langmann, T.; Dietmaier, W.; Landthaler, M.; Vogt, T. Differential Gene Expression of Eph Receptors and Ephrins in Benign Human Tissues and Cancers. Clin. Chem. 2004, 50, 490-499. [CrossRef]

67. Woodruff, T.M.; Wu, M.C.-L.; Morgan, M.; Bain, N.T.; Jeanes, A.; Lipman, J.; Ting, M.J.; Boyd, A.W.; Taylor, S.M.; Coulthard, M. Epha4-Fc Treatment Reduces Ischemia/Reperfusion-Induced Intestinal Injury by Inhibiting Vascular Permeability. Shock 2016, 45, 184-191. [CrossRef]

68. Ivanov, A.I.; Romanovsky, A.A. Putative dual role of ephrin-Eph receptor interactions in inflammation. IUBMB Life 2006, 58, 389-394. [CrossRef]

69. Hordijk, P.L. Recent insights into endothelial control of leukocyte extravasation. Cell. Mol. Life Sci. 2016, 73, 1591-1608. [CrossRef]

70. Tosato, G. Ephrin ligands and Eph receptors contribution to hematopoiesis. Cell. Mol. Life Sci. 2017, 74, 3377-3394. [CrossRef]

71. Liu, H.; Devraj, K.; Möller, K.; Liebner, S.; Hecker, M.; Korff, T. EphrinB-mediated reverse signalling controls junctional integrity and pro-inflammatory differentiation of endothelial cells. Thromb. Haemost. 2014, 112, 151-163. [CrossRef] [PubMed]

72. Trinidad, E.M.; Ballesteros, M.; Zuloaga, J.; Zapata, A.G.; Alonso-Colmenar, L.M. An impaired transendothelial migration potential of chronic lymphocytic leukemia (CLL) cells can be linked to ephrin-A4 expression. Blood 2009, 114, 5081-5090. [CrossRef] [PubMed]

73. Sepehri, Z.; Kiani, Z.; Kohan, F.; Alavian, S.M.; Ghavami, S. Toll like receptor 4 and hepatocellular carcinoma; A systematic review. Life Sci. 2017, 179, 80-87. [CrossRef] [PubMed]

74. Mukai, M.; Suruga, N.; Saeki, N.; Ogawa, K. EphA receptors and ephrin-A ligands are upregulated by monocytic differentiation/maturation and promote cell adhesion and protrusion formation in HL60 monocytes. BMC Cell Boil. 2017, 18, 28. [CrossRef] [PubMed]

75. Muñoz, J.J.; Alonso-Colmenar, L.M.; Sacedón, R.; Crompton, T.; Vicente, A.; Jimenez, E.; Varas, A.; Zapata, A.G. Expression and function of the Eph A receptors and their ligands ephrins A in the rat thymus. J. Immunol. 2002, 169, 177-184. [CrossRef] [PubMed]

76. Wu, J.; Luo, H. Recent advances on T-cell regulation by receptor tyrosine kinases. Curr. Opin. Hematol. 2005, 12, 292-297. [CrossRef] [PubMed]

77. Sharfe, N.; Freywald, A.; Toro, A.; Dadi, H.; Roifman, C.M. Ephrin stimulation modulates T? Cell chemotaxis. Eur. J. Immunol. 2002, 32, 3745-3755. [CrossRef]

78. Salvucci, O.; Tosato, G. Essential Roles of EphB Receptors and EphrinB Ligands in Endothelial Cell Function and Angiogenesis. Adv. Cancer Res. 2012, 114, 21-57. [CrossRef]

79. Wolf, K.; Hu, H.; Isaji, T.; Dardik, A. Molecular identity of arteries, veins, and lymphatics. J. Vasc. Surg. 2018, 69, 253-262. [CrossRef]

80. Henderson, N.T.; Dalva, M.B. EphBs and ephrin-Bs: Trans-synaptic organizers of synapse development and function. Mol. Cell. Neurosci. 2018, 91, 108-121. [CrossRef]

81. Cibert-Goton, V.; Yuan, G.; Battaglia, A.; Fredriksson, S.; Henkemeyer, M.; Sears, T.; Gavazzi, I. Involvement of EphB1 Receptors Signalling in Models of Inflammatory and Neuropathic Pain. PLoS ONE 2013, 8, e53673. [CrossRef] [PubMed]

82. Alonso-Colmenar, L.M.; Trinidad, E.M.; Garcillán, B.; Ballesteros, M.; Castellanos, M.; Cotillo, I.; Muñoz, J.J.; Zapata, A.G. Expression profile of Eph receptors and ephrin ligands in healthy human B lymphocytes and chronic lymphocytic leukemia B-cells. Leuk. Res. 2009, 33, 395-406. [CrossRef] [PubMed]

83. Wybenga-Groot, L.E.; McGlade, C.J. Rtk Slap Down: The emerging role of Src-like adaptor protein as a key player in receptor tyrosine kinase signaling. Cell. Signal. 2015, 27, 267-274. [CrossRef] [PubMed]

84. Aitsebaomo, J.; Portbury, A.L.; Schisler, J.C.; Patterson, C. Brothers, and sisters: Molecular insights into arterial-venous heterogeneity. Circ. Res. 2008, 103, 929-939. [CrossRef] 
85. Coso, S.; Bovay, E.; Petrova, T.V. Pressing the right buttons: Signaling in lymphangiogenesis. Blood 2014, 123, 2614-2624. [CrossRef]

86. Makinen, T.; Adams, R.H.; Bailey, J.; Lu, Q.; Ziemiecki, A.; Alitalo, K.; Klein, R.; Wilkinson, G.A. PDZ interaction site in ephrinB2 is required for the remodeling of lymphatic vasculature. Genome Res. 2005, 19, 397-410. [CrossRef]

87. Lodola, A.; Giorgio, C.; Incerti, M.; Zanotti, I.; Tognolini, M. Targeting Eph/ephrin system in cancer therapy. Eur. J. Med. Chem. 2017, 142, 152-162. [CrossRef]

88. Magic, Z.; Sandström, J.; Perez-Tenorio, G. Ephrin-B2 inhibits cell proliferation and motility in vitro and predicts longer metastasis-free survival in breast cancer. Int. J. Oncol. 2019, 55. [CrossRef]

89. Abéngozar, M.A.; de Frutos, S.; Ferreiro, S.; Soriano, J.; Perez-Martinez, M.; Olmeda, D.; Marenchino, M.; Cañamero, M.; Ortega, S.; Megias, D.; et al. Blocking ephrinB2 with highly specific antibodies inhibits angiogenesis, lymphangiogenesis, and tumor growth. Blood 2012, 119, 4565-4576. [CrossRef]

90. Alfaro, D.; Zapata, A.G. Eph/Ephrin-mediated stimulation of human bone marrow mesenchymal stromal cells correlates with changes in cell adherence and increased cell death. Stem Cell Res. Ther. 2018, 9, 172. [CrossRef]

91. Nguyen, T.M.; Arthur, A.; Panagopoulos, R.; Paton, S.; Hayball, J.D.; Zannettino, A.C.; Purton, L.; Matsuo, K.; Gronthos, S. EphB4 Expressing Stromal Cells Exhibit an Enhanced Capacity for Hematopoietic Stem Cell Maintenance. Stem Cells 2015, 33, 2838-2849. [CrossRef] [PubMed]

92. Nguyen, T.M.; Arthur, A.; Gronthos, S. The role of Eph/ephrin molecules in stromal-hematopoietic interactions. Int. J. Hematol. 2015, 103, 145-154. [CrossRef] [PubMed]

93. Fernandez-Alonso, R.; Bustos, F.; Budzyk, M.; Kumar, P.; Helbig, A.O.; Hukelmann, J.; Lamond, A.I.; Lanner, F.; Zhou, H.; Petsalaki, E.; et al. Phosphoproteomics identifies a bimodal EPHA2 receptor switch that promotes embryonic stem cell differentiation. Nat. Commun. 2020, 11, 1-13. [CrossRef] [PubMed]

94. Lee, J.; Nakajima-Koyama, M.; Sone, M.; Koga, M.; Ebisuya, M.; Yamamoto, T. Secreted Ephrin Receptor A7 Promotes Somatic Cell Reprogramming by Inducing ERK Activity Reduction. Stem. Cell Rep. 2015, 5, 480-489. [CrossRef] [PubMed]

95. Jung, Y.H.; Lee, S.-J.; Oh, S.Y.; Lee, H.J.; Ryu, J.M.; Han, H.J. Oleic acid enhances the motility of umbilical cord blood derived mesenchymal stem cells through EphB2-dependent F-actin formation. Biochim. Biophys. Acta Bioenerg. 2015, 1853, 1905-1917. [CrossRef]

96. Fujiwara, H.; Ono, M.; Sato, Y.; Imakawa, K.; Iizuka, T.; Kagami, K.; Fujiwara, T.; Horie, A.; Tani, H.; Hattori, A.; et al. Promoting Roles of Embryonic Signals in Embryo Implantation and Placentation in Cooperation with Endocrine and Immune Systems. Int. J. Mol. Sci. 2020, 21, 1885. [CrossRef]

97. Yang, D.; Wang, Y.; Jiang, M.; Deng, X.; Pei, Z.; Li, F.; Xia, K.; Zhu, L.; Yang, T.; Chen, M. Downregulation of Profilin-1 Expression Attenuates Cardiomyocytes Hypertrophy and Apoptosis Induced by Advanced Glycation End Products in H9c2 Cells. BioMed Res. Int. 2017, 2017, 1-11. [CrossRef]

98. Hartmann, S.; Ridley, A.J.; Lutz, S. The Function of Rho-Associated Kinases ROCK1 and ROCK2 in the Pathogenesis of Cardiovascular Disease. Front. Pharmacol. 2015, 6, 385. [CrossRef]

99. Liu, Y.; Tejpal, N.; You, J.; Li, X.C.; Ghobrial, R.M.; Kloc, M. ROCK inhibition impedes macrophage polarity and functions. Cell. Immunol. 2016, 300, 54-62. [CrossRef]

100. Sharfe, N.; Nikolic, M.; Cimpeon, L.; van de Kratts, A.; Freywald, A.; Roifman, C.M. EphA and ephrin-A proteins regulate integrin-mediated T lymphocyte interactions. Mol. Immunol. 2008, 45, 1208-1220. [CrossRef]

101. Cowan, C.A.; Henkemeyer, M. The SH2/SH3 adaptor Grb4 transduces B-ephrin reverse signals. Nature 2001, 413, 174-179. [CrossRef] [PubMed]

102. Park, I.; Lee, H.-S. EphB/ephrinB signaling in cell adhesion and migration. Mol. Cells 2014, 38, 14-19. [CrossRef] [PubMed]

103. Prospéri, M.-T.; Lépine, P.; Dingli, F.; Paul-Gilloteaux, P.; Martin, R.; Loew, D.; Knölker, H.-J.; Coudrier, E. Myosin $1 \mathrm{~b}$ functions as an effector of EphB signaling to control cell repulsion. J. Cell Boil. 2015, 210, 347-361. [CrossRef] [PubMed]

104. Yamazaki, T.; Masuda, J.; Omori, T.; Usui, R.; Akiyama, H.; Maru, Y. EphA1 interacts with integrin-linked kinase and regulates cell morphology and motility. J. Cell Sci. 2008, 122, 243-255. [CrossRef] [PubMed]

105. Lee, H.-H.; Chang, Z.-F. Regulation of RhoA-dependent ROCKII activation by Shp2. J. Cell Boil. 2008, 181, 999-1012. [CrossRef] 
106. Miao, H.; Burnett, E.; Kinch, M.; Simon, E.; Wang, B. Activation of EphA2 kinase suppresses integrin function and causes focal-adhesion-kinase dephosphorylation. Nature 1999, 2, 62. [CrossRef]

107. Olgar, Y.; Celen, M.; Yamasan, B.E.; Ozturk, N.; Turan, B.; Ozdemir, S. Rho-kinase inhibition reverses impaired Ca 2+ handling and associated left ventricular dysfunction in pressure overload-induced cardiac hypertrophy. Cell Calcium 2017, 67, 81-90. [CrossRef]

108. Brand, C.S.; Tan, V.P.; Brown, J.H.; Miyamoto, S. RhoA regulates Drp1 mediated mitochondrial fission through ROCK to protect cardiomyocytes. Cell. Signal. 2018, 50, 48-57. [CrossRef]

109. He, K.; Yan, L.; Pan, C.-S.; Liu, Y.-Y.; Cui, Y.-C.; Hu, B.-H.; Chang, X.; Li, Q.; Sun, K.; Mao, X.-W.; et al. ROCK-dependent ATP5D modulation contributes to the protection of notoginsenoside NR1 against ischemia-reperfusion-induced myocardial injury. Am. J. Physiol. Circ. Physiol. 2014, 307, 1764-1776. [CrossRef]

110. Bian, H.; Zhou, Y.; Yu, B.; Shang, D.; Liu, F.; Li, B.; Qi, J. Rho-kinase signaling pathway promotes the expression of PARP to accelerate cardiomyocyte apoptosis in ischemia/reperfusion. Mol. Med. Rep. 2017, 16, 2002-2008. [CrossRef]

111. Shi, J.; Surma, M.; Yang, Y.; Wei, L. Disruption of both ROCK1 and ROCK2 genes in cardiomyocytes promotes autophagy and reduces cardiac fibrosis during aging. FASEB J. 2019, 33, 7348-7362. [CrossRef] [PubMed]

112. Pegg, C.; Cooper, L.T.; Zhao, J.; Gerometta, M.; Smith, F.M.; Yeh, M.; Bartlett, P.F.; Gorman, J.J.; Boyd, A.W. Glycoengineering of EphA4 Fc leads to a unique, long-acting and broad spectrum, Eph receptor therapeutic antagonist. Sci. Rep. 2017, 7, 6519. [CrossRef] [PubMed]

113. Scheideler, O.J.; Yang, C.; Kozminsky, M.; Mosher, K.I.; Falcón-Banchs, R.; Ciminelli, E.C.; Bremer, A.W.; Chern, S.A.; Schaffer, D.V.; Sohn, L.L. Recapitulating complex biological signaling environments using a multiplexed, DNA-patterning approach. Sci. Adv. 2020, 6, e5696. [CrossRef] [PubMed]

114. Noberini, R.; Lamberto, I.; Pasquale, E.B. Targeting Eph receptors with peptides and small molecules: Progress and challenges. Semin. Cell Dev. Boil. 2011, 23, 51-57. [CrossRef] [PubMed]

115. Soler, M.M.G.; Gehring, M.P.; Lechtenberg, B.C.; Zapata-Mercado, E.; Hristova, K.; Pasquale, E.B. Engineering nanomolar peptide ligands that differentially modulate EphA2 receptor signaling. J. Boil. Chem. 2019, 294, 8791-8805. [CrossRef] [PubMed]

116. Alves, D.S.; Westerfield, J.M.; Shi, X.; Nguyen, V.P.; Stefanski, K.M.; Booth, K.R.; Kim, S.; Morrell-Falvey, J.L.; Wang, B.; Abel, S.; et al. A novel pH-dependent membrane peptide that binds to EphA2 and inhibits cell migration. eLife 2018, 7. [CrossRef]

117. Gambini, L.; Salem, A.F.; Udompholkul, P.; Tan, X.-F.; Baggio, C.; Shah, N.; Aronson, A.; Song, J.; Pellecchia, M. Structure-Based Design of Novel EphA2 Agonistic Agents with Nanomolar Affinity in Vitro and in Cell. ACS Chem. Boil. 2018, 13, 2633-2644. [CrossRef]

118. Wu, B.; De, S.K.; Kulinich, A.; Salem, A.F.; Koeppen, J.; Wang, R.; Barile, E.; Wang, S.; Zhang, D.; Ethell, I.; et al. Potent and Selective EphA4 Agonists for the Treatment of ALS. Cell Chem. Boil. 2017, 24, $293-305$. [CrossRef]

119. Heinzlmeir, S.; Kudlinzki, D.; Sreeramulu, S.; Klaeger, S.; Gande, S.L.; Linhard, V.; Wilhelm, M.; Qiao, H.; Helm, D.; Ruprecht, B.; et al. Chemical Proteomics and Structural Biology Define EPHA2 Inhibition by Clinical Kinase Drugs. ACS Chem. Boil. 2016, 11, 3400-3411. [CrossRef]

120. Miao, B.; Ji, Z.; Tan, L.; Taylor, M.; Zhang, J.; Choi, H.G.; Frederick, D.T.; Kumar, R.; Wargo, J.A.; Flaherty, K.T.; et al. EPHA2 is a mediator of vemurafenib resistance and a novel therapeutic target in melanoma. Cancer Discov. 2014, 5, 274-287. [CrossRef]

121. Giorgio, C.; Incerti, M.; Corrado, M.; Presta, M.; Chiodelli, P.; Russo, S.; Callegari, D.; Ferlenghi, F.; Ballabeni, V.; Barocelli, E.; et al. Pharmacological evaluation of new bioavailable small molecules targeting Eph/ephrin interaction. Biochem. Pharmacol. 2018, 147, 21-29. [CrossRef] [PubMed]

122. Giorgio, C.; Incerti, M.; Pala, D.; Russo, S.; Chiodelli, P.; Rusnati, M.; Cantoni, A.; di Lecce, R.; Barocelli, E.; Bertoni, S.; et al. Inhibition of Eph/ephrin interaction with the small molecule UniPR500 improves glucose tolerance in healthy and insulin-resistant mice. Pharmacol. Res. 2019, 141, 319-330. [CrossRef] [PubMed]

123. Dai, B.; Shi, X.; Ma, N.; Ma, W.; Zhang, Y.; Yang, T.; Zhang, J.; He, L. HMQ-T-B10 induces human liver cell apoptosis by competitively targeting EphrinB2 and regulating its pathway. J. Cell. Mol. Med. 2018, 22, 5231-5243. [CrossRef] [PubMed]

124. Ma, W.; Zhu, M.; Zhang, D.; Yang, L.; Yang, T.; Li, X.; Zhang, Y. Berberine inhibits the proliferation and migration of breast cancer ZR-75-30 cells by targeting Ephrin-B2. Phytomedicine 2017, 25, 45-51. [CrossRef] 
125. Ma, W.; Zhu, M.; Yang, L.; Yang, T.; Zhang, Y. Synergistic Effect of TPD7 and Berberine against Leukemia Jurkat Cell Growth through Regulating Ephrin-B2 Signaling. Phytother. Res. 2017, 31, 1392-1399. [CrossRef]

126. Riedl, S.J.; Pasquale, E.B. Targeting the Eph System with Peptides and Peptide Conjugates. Curr. Drug Targets 2015, 16, 1031-1047. [CrossRef]

127. Salem, A.F.; Wang, S.; Billet, S.; Chen, J.-F.; Udompholkul, P.; Gambini, L.; Baggio, C.; Tseng, H.; Posadas, E.M.; Bhowmick, N.A.; et al. Reduction of Circulating Cancer Cells and Metastases in Breast-Cancer Models by a Potent EphA2-Agonistic Peptide-Drug Conjugate. J. Med. Chem. 2018, 61, 2052-2061. [CrossRef]

128. Wu, B.; Wang, S.; De, S.K.; Barile, E.; Quinn, B.A.; Zharkikh, I.; Purves, A.; Stebbins, J.L.; Oshima, R.G.; Fisher, P.B.; et al. Design and Characterization of Novel EphA2 Agonists for Targeted Delivery of Chemotherapy to Cancer Cells. Chem. Boil. 2015, 22, 876-887. [CrossRef]

129. Barile, E.; Wang, S.; Das, S.K.; Noberini, R.; Dahl, R.; Stebbins, J.L.; Pasquale, E.B.; Fisher, P.B.; Pellecchia, M. Design, synthesis and bioevaluation of an EphA2 receptor-based targeted delivery system. Chem. Med. Chem. 2014, 9, 1403-1412. [CrossRef]

130. Wang, S.; Placzek, W.J.; Stebbins, J.L.; Mitra, S.; Noberini, R.; Koolpe, M.; Zhang, Z.; Dahl, R.; Pasquale, E.B.; Pellecchia, M. Novel Targeted System To Deliver Chemotherapeutic Drugs to EphA2-Expressing Cancer Cells. J. Med. Chem. 2012, 55, 2427-2436. [CrossRef]

131. Quinn, B.A.; Wang, S.; Barile, E.; Das, S.K.; Emdad, L.; Sarkar, D.; De, S.K.; Kharagh, S.M.; Stebbins, J.L.; Pandol, S.J.; et al. Therapy of pancreatic cancer via an EphA2 receptor-targeted delivery of gemcitabine. Oncotarget 2016, 7, 17103-17110. [CrossRef] [PubMed]

132. Jacobson, O.; Li, Q.; Chen, H.; Niu, G.; Kiesewetter, D.O.; Xu, L.; Cook, K.; Yang, G.; Dall'Acqua, W.; Tsui, P.; et al. PET-Guided Evaluation and Optimization of Internalized Antibody-Drug Conjugates Targeting Erythropoietin-Producing Hepatoma A2 Receptor. J. Nucl. Med. 2017, 58, 1838-1844. [CrossRef] [PubMed]

133. Damelin, M.; Bankovich, A.; Park, A.; Aguilar, J.; Anderson, W.; Santaguida, M.; Aujay, M.; Fong, S.; Khandke, K.; Pulito, V.; et al. Anti-EFNA4 Calicheamicin Conjugates Effectively Target Triple-Negative Breast and Ovarian Tumor-Initiating Cells to Result in Sustained Tumor Regressions. Clin. Cancer Res. 2015, 21, 4165-4173. [CrossRef] [PubMed]

134. Bhatia, S.; Hirsch, K.; Sharma, J.; Oweida, A.; Griego, A.; Keysar, S.; Jimeno, A.; Raben, D.; Krasnoperov, V.; Gill, P.S.; et al. Enhancing radiosensitization in EphB4 receptor-expressing Head and Neck Squamous Cell Carcinomas. Sci. Rep. 2016, 6, 38792. [CrossRef]

135. Ferluga, S.; Tomé, C.M.L.; Herpai, D.M.; D'Agostino, R.; Debinski, W. Simultaneous targeting of Eph receptors in glioblastoma. Oncotarget 2016, 7, 59860-59876. [CrossRef]

136. Qazi, M.; Vora, P.; Venugopal, C.; Adams, J.; Singh, M.; Hu, A.X.; Gorelik, M.; Subapanditha, M.K.; Savage, N.; Yang, J.; et al. Cotargeting Ephrin Receptor Tyrosine Kinases A2 and A3 in Cancer Stem Cells Reduces Growth of Recurrent Glioblastoma. Cancer Res. 2018, 78, 5023-5037. [CrossRef]

137. Stephenson, S.-A.; Douglas, E.L.; Mertens-Walker, I.; Lisle, J.; Maharaj, M.S.; Herington, A.C. Anti-tumour effects of antibodies targeting the extracellular cysteine-rich region of the receptor tyrosine kinase EphB4. Oncotarget 2015, 6, 7554-7569. [CrossRef]

138. Özcan, G.; Ozpolat, B.; Coleman, R.L.; Sood, A.K.; Lopez-Berestein, G. Preclinical and clinical development of siRNA-based therapeutics. Adv. Drug Deliv. Rev. 2015, 87, 108-119. [CrossRef]

139. Bhatia, S.; Hirsch, K.; Bukkapatnam, S.; Baig, N.A.; Oweida, A.; Griego, A.; Calame, D.; Sharma, J.; Donson, A.; Foreman, N.K.; et al. Combined EphB2 receptor knockdown with radiation decreases cell viability and invasion in medulloblastoma. Cancer Cell Int. 2017, 17, 41. [CrossRef]

140. Ma, T.; Liu, X.; Cen, Z.; Xin, C.; Guo, M.; Zou, C. MicroRNA-302b negatively regulates IL-1beta production in response to MSU crystals by targeting IRAK4 and EphA2. Arthr. Res.Ther. 2018, 20, 34. [CrossRef]

141. Jin, Q.; Li, X.J.; Cao, P.G. MicroRNA-26b Enhances the Radiosensitivity of Hepatocellular Carcinoma Cells by Targeting EphA2. Tohoku J. Exp. Med. 2016, 238, 143-151. [CrossRef] [PubMed]

142. Alavi, M.; Hamidi, M. Passive and active targeting in cancer therapy by liposomes and lipid nanoparticles. Drug Metab. Pers. Ther. 2019, 34. [CrossRef] [PubMed]

143. Su, C.-Y.; Chen, M.; Chen, L.-C.; Ho, Y.-S.; Ho, H.-O.; Lin, S.-Y.; Chuang, K.-H.; Sheu, M.-T. Bispecific antibodies (anti-mPEG/anti-HER2) for active tumor targeting of docetaxel (DTX)-loaded mPEGylated nanocarriers to enhance the chemotherapeutic efficacy of HER2-overexpressing tumors. Drug Deliv. 2018, 25, 1066-1079. [CrossRef] [PubMed] 
144. Ulbrich, K.; Holá, K.; Subr, V.; Bakandritsos, A.; Tucek, J.; Zbořil, R. Targeted Drug Delivery with Polymers and Magnetic Nanoparticles: Covalent and Noncovalent Approaches, Release Control, and Clinical Studies. Chem. Rev. 2016, 116, 5338-5431. [CrossRef] [PubMed]

145. Ekladious, I.; Colson, Y.L.; Grinstaff, M.W. Polymer-drug conjugate therapeutics: Advances, insights, and prospects. Nat. Rev. Drug Discov. 2018, 18, 273-294. [CrossRef] [PubMed]

146. Haghiralsadat, F.; Amoabediny, G.; Naderinezhad, S.; Doulabi, B.Z.; Forouzanfar, T.; Helder, M.N. Codelivery of doxorubicin and JIP1 siRNA with novel EphA2-targeted PEGylated cationic nanoliposomes to overcome osteosarcoma multidrug resistance. Int. J. Nanomed. 2018, 13, 3853-3866. [CrossRef]

147. Zhang, J.; Du, Z.; Pan, S.; Shi, M.; Li, J.; Yang, C.; Hu, H.; Qiao, M.; Chen, D.; Zhao, X. Overcoming Multidrug Resistance by Codelivery of MDR1-Targeting siRNA and Doxorubicin Using EphA10-Mediated pH-Sensitive Lipoplexes: In Vitro and In Vivo Evaluation. ACS Appl. Mater. Interfaces 2018, 10, 21590-21600. [CrossRef]

148. Guo, Z.; He, B.; Yuan, L.; Dai, W.; Zhang, H.; Wang, X.; Wang, J.; Zhang, X.; Zhang, Q. Dual targeting for metastatic breast cancer and tumor neovasculature by EphA2-mediated nanocarriers. Int. J. Pharm. 2015, 493, 380-389. [CrossRef]

149. Nasreen, N.; Lee, H.-Y.; A Mohammed, K.; Kaye, F.; Sharma, P.; Moudgil, B.M.; Clapp, W.L. Targeted delivery of let-7a microRNA encapsulated ephrin-A1 conjugated liposomal nanoparticles inhibit tumor growth in lung cancer. Int. J. Nanomed. 2013, 8, 4481-4494. [CrossRef]

150. Huang, Z.R.; Tipparaju, S.K.; Kirpotin, D.B.; Pien, C.; Kornaga, T.; Noble, C.O.; Koshkaryev, A.; Tran, J.; Kamoun, W.S.; Drummond, D.C. Formulation optimization of an ephrin A2 targeted immunoliposome encapsulating reversibly modified taxane prodrugs. J. Control. Release 2019, 310, 47-57. [CrossRef]

151. Zhang, K.; Geddie, M.L.; Kohli, N.; Kornaga, T.; Kirpotin, D.B.; Jiao, Y.; Rennard, R.; Drummond, D.C.; Nielsen, U.B.; Xu, L.; et al. Comprehensive optimization of a single-chain variable domain antibody fragment as a targeting ligand for a cytotoxic nanoparticle. $m A$ As 2015, 7, 42-52. [CrossRef] [PubMed]

152. Geddie, M.L.; Kohli, N.; Kirpotin, D.B.; Razlog, M.; Jiao, Y.; Kornaga, T.; Rennard, R.; Xu, L.; Schoerberl, B.; Marks, J.D.; et al. Improving the developability of an anti-EphA2 single-chain variable fragment for nanoparticle targeting. MAB's 2016, 9, 58-67. [CrossRef] [PubMed]

153. Pearce, A.K.; Fuchs, A.V.; Fletcher, N.L.; Thurecht, K.J. Targeting Nanomedicines to Prostate Cancer: Evaluation of Specificity of Ligands to Two Different Receptors In Vivo. Pharm. Res. 2016, 33, 2388-2399. [CrossRef] [PubMed]

154. Blevins, K.S.; Jeong, J.H.; Ou, M.; Brumbach, J.H.; Kim, S.W. EphA2 targeting peptide tethered bioreducible poly (cystamine bisacrylamide-diamino hexane) for the delivery of therapeutic pCMV-RAE-1gamma to pancreatic islets. J. Control Release 2012, 158, 115-122. [CrossRef]

155. Conway, A.; Vazin, T.; Spelke, D.P.; Rode, N.A.; Healy, K.E.; Kane, R.S.; Schaffer, D.V. Multivalent ligands control stem cell behaviour in vitro and in vivo. Nat. Nanotechnol. 2013, 8, 831-838. [CrossRef]

156. Möser, C.; Lorenz, J.S.; Sajfutdinow, M.; Smith, D.M. Pinpointed Stimulation of EphA2 Receptors via DNA-Templated Oligovalence. Int. J. Mol. Sci. 2018, 19, 3482. [CrossRef]

157. Patel, A.R.; Chougule, M.; Singh, M. EphA2 targeting pegylated nanocarrier drug delivery system for treatment of lung cancer. Pharm. Res. 2014, 31, 2796-2809. [CrossRef]

158. Ou, W.; Byeon, J.H.; Soe, Z.C.; Kim, B.K.; Thapa, R.K.; Gupta, B.; Poudel, B.K.; Ku, S.K.; Yong, C.S.; Kim, J.O. Tailored Black Phosphorus for Erythrocyte Membrane Nanocloaking with Interleukin-1 $\alpha$ siRNA and Paclitaxel for Targeted, Durable, and Mild Combination Cancer Therapy. Theranostics 2019, 9, 6780-6796. [CrossRef]

159. Alkilany, A.; Boulos, S.P.; Lohse, S.E.; Thompson, L.; Murphy, C. Homing Peptide-Conjugated Gold Nanorods: The Effect of Amino Acid Sequence Display on Nanorod Uptake and Cellular Proliferation. Bioconjugate Chem. 2014, 25, 1162-1171. [CrossRef]

160. Hanley, T.; Yin, R.; Mac, J.T.; Tan, W.; Anvari, B. Functionalized erythrocyte-derived optical nanoparticles to target ephrin-B2 ligands. J. Biomed. Opt. 2019, 24, 85002-85009. [CrossRef]

161. Chu, L.; Wang, A.; Ni, L.; Yan, X.; Song, Y.; Zhao, M.; Sun, K.; Mu, H.; Liu, S.; Wu, Z.; et al. Nose-to-brain delivery of temozolomide-loaded PLGA nanoparticles functionalized with anti-EPHA3 for glioblastoma targeting. Drug Deliv. 2018, 25, 1634-1641. [CrossRef] [PubMed] 
162. Patil, M.; Upadhyay, A.K.; Hernandez-Lagunas, L.; Good, R.; Carpenter, T.C.; Sucharov, C.C.; Nozik-Grayck, E.; Kompella, U.B. Targeted delivery of YSA-functionalized and non-functionalized polymeric nanoparticles to injured pulmonary vasculature. Artif. Cells Nanomed. Biotechnol. 2018, 46, 1059-1066. [CrossRef] [PubMed]

163. Li, M.; Wang, B.; Wu, Z.; Shi, X.; Zhang, J.; Han, S. Treatment of Dutch rat models of glioma using Ephrin-A1-PE38/GM-CSF chitosan nanoparticles by in situ activation of dendritic cells. Tumour Biol. 2015, 36, 7961-7966. [CrossRef] [PubMed]

164. Pasquale, E.B. Exosomes expand the sphere of influence of Eph receptors and ephrins. J. Cell Boil. 2016, 214, 5-7. [CrossRef]

165. Gong, J.; Körner, R.; Gaitanos, L.; Klein, R. Exosomes mediate cell contact-independent ephrin-Eph signaling during axon guidance. J. Cell Boil. 2016, 214, 35-44. [CrossRef]

166. Zhao, Y.; Yin, L.; Zhang, H.; Lan, T.; Li, S.; Ma, P. Eph/ephrin family anchored on exosome facilitate communications between cells. Cell Boil. Int. 2018, 42, 1458-1462. [CrossRef]

167. Sato, S.; Vasaikar, S.; Eskaros, A.; Kim, Y.; Lewis, J.S.; Zhang, B.; Zijlstra, A.; Weaver, A.M. EPHB2 carried on small extracellular vesicles induces tumor angiogenesis via activation of ephrin reverse signaling. JCI Insight 2019, 4. [CrossRef]

168. Yamashita, T.; Kamada, H.; Kanasaki, S.; Nagano, K.; Inoue, M.; Higashisaka, K.; Yoshioka, Y.; Tsutsumi, Y.; Tsunoda, S. Ephrin type-A receptor 2 on tumor-derived exosomes enhances angiogenesis through the activation of MAPK signaling. Pharmazie 2019, 74, 614-619.

169. Fan, J.; Wei, Q.; Koay, E.J.; Liu, Y.; Ning, B.; Bernard, P.W.; Zhang, N.; Han, H.; Katz, M.H.; Zhao, Z.; et al. Chemoresistance Transmission via Exosome-Mediated EphA2 Transfer in Pancreatic Cancer. Theranostics 2018, 8, 5986-5994. [CrossRef]

170. Jung, K.O.; Youn, H.; Lee, C.-H.; Kang, K.W.; Chung, J.-K. Visualization of exosome-mediated miR-210 transfer from hypoxic tumor cells. Oncotarget 2016, 8, 9899-9910. [CrossRef]

171. Liu, H.; Wang, J.; Chen, Y.; Chen, Y.; Ma, X.; Bihl, J.; Yang, Y. NPC-EXs Alleviate Endothelial Oxidative Stress and Dysfunction through the miR-210 Downstream Nox2 and VEGFR2 Pathways. Oxid. Med. Cell. Longev. 2017, 2017, 1-11. [CrossRef] [PubMed]

172. Barile, L.; Lionetti, V.; Cervio, E.; Matteucci, M.; Gherghiceanu, M.; Popescu, L.M.; Torre, T.; Siclari, F.; Moccetti, T.; Vassalli, G. Extracellular vesicles from human cardiac progenitor cells inhibit cardiomyocyte apoptosis and improve cardiac function after myocardial infarction. Cardiovasc. Res. 2014, 103, 530-541. [CrossRef] [PubMed]

(C) 2020 by the authors. Licensee MDPI, Basel, Switzerland. This article is an open access article distributed under the terms and conditions of the Creative Commons Attribution (CC BY) license (http://creativecommons.org/licenses/by/4.0/). 